\title{
Serum Micronutrient and Micromineral Concentrations and Ratios in Healthy Omani Subjects
}

\author{
Clifford Abiaka ${ }^{a}$ Mohammed Al-Tobi ${ }^{a}$ Ravi Joshi ${ }^{b}$

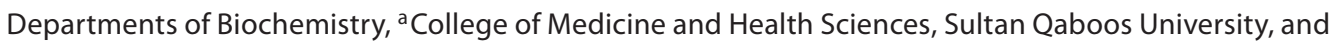 \\ bSultan Qaboos University Hospital, Al-Khoudh, Oman
}

\author{
Key Words \\ Omani $\cdot \alpha$-Tocopherol $\cdot$ Caeruloplasmin $\cdot$ Cholesterol . \\ Copper $\cdot$ Retinol $\cdot$ Zinc
}

\begin{abstract}
Objective: This study aimed to establish reference ranges of serum concentrations of copper, zinc, retinol, $\alpha$-tocopherol, copper:caeruloplasmin and copper:zinc ratios in a group of healthy Omani men and women. Materials and Methods: Assay techniques employed were atomic absorption spectrophotometry (copper and zinc), reverse-phase high-pressure liquid chromatography with isocratic elution (retinol and $\alpha$-tocopherol), immunonephelometry (caeruloplasmin) and spectrophotometry (albumin and cholesterol). Results: The mean \pm SD $(\mu \mathrm{M})$ obtained for copper, zinc, retinol, and $\alpha$-tocopherol were $15.9 \pm 3.0,14.2 \pm 2.0,1.45 \pm 0.39$ and $16.9 \pm 4.4$, respectively. The mean \pm SD for copper:zinc and copper:caeruloplasmin ratios were $1.15 \pm 0.30 \mu \mathrm{mol} / \mathrm{mmol}$ and $6.99 \pm 0.84 \mu \mathrm{mol} / \mathrm{g}$, respectively. Significantly higher ( $p<0.0001$ ) copper and caeruloplasmin concentrations, copper:zinc and copper:caeruloplasmin ratios and lower zinc, retinol, $\alpha$-tocopherol, cholesterol concentrations and $\alpha$-tocopherol:cholesterol ratio were present in women compared to men. Age appeared to be associated with copper and retinol concentrations, and copper:caeruloplasmin ratios in women; in men, the association was mostly moderate with caeruloplasmin, $\alpha$-tocopherol, cholesterol concentra-
\end{abstract}

tions and $\alpha$-tocopherol:cholesterol ratios. Smokers had decreased albumin ( $p=0.002)$, zinc ( $p=0.023$ ) concentrations, and copper:caeruloplasmin ratios ( $p=0.002)$, increased $\alpha$-tocopherol concentrations $(p=0.016)$ and $\alpha$-tocopherol:cholesterol ratios $(p=0.021)$ compared with non-smokers. Deficiency incidence was $\leq 5 \%$ for all investigated parameters. Conclusions: Reference ranges of micronutrient concentrations and micromineral ratios were established for Omani subjects. The mean values of several micronutrients were lower than those reported for other populations and some showed gender effects.

Copyright $\odot 2008$ S. Karger AG, Base

\section{Introduction}

In the Sultanate of Oman, estimated occurrences of nutritional disorders per 10,000 population are malnutrition (protein energy malnutrition, vitamin A mineral deficiencies) 19, obesity and other metabolic disorders (excluding gout) 9, other nutritional deficiencies and symptoms related to nutrition and development 9, thus making a total of $37(0.37 \%)$ [1]. In this context, information about micronutrient status of the people of this region is lacking. The present study embarked on the investigation of levels of copper, zinc, retinol, and $\alpha$-tocopherol and micromineral ratios in healthy Omani men and women.

\section{KARGER}

Fax +41613061234

E-Mail karger@karger.ch

www.karger.com (c) 2008 S. Karger AG, Basel

$1011-7571 / 08 / 0174-0334 \$ 24.50 / 0$

Accessible online at:

www.karger.com/mpp
Dr. Clifford D. Abiaka

Department of Biochemistry, College of Medicine and Health Sciences Sultan Qaboos University, PO Box 35

Al-Khoudh 123 (Oman)

Tel. +9689504 5630, Fax +9682453 5630, E-Mail clifab@hotmail.com 
The microminerals copper and zinc are essential enzyme cofactors and antioxidants [2]. Copper is an important mineral in the normal growth and development of the skeletal system [2]. Zinc status regulates vitamin A metabolism, including absorption, transport and its utilization [3] and its deficiency is associated with decrease in bone density. Zinc is bound mainly to plasma albumin [2], which is considered a nutrition marker [4]. It also inhibits the intestinal absorption of copper. Hence, the risk of copper deficiency is increased when the molar ratio of zinc to copper $(\mathrm{Zn}: \mathrm{Cu})$ is high [5]. Copper:zinc ratio is thought to be clinically more useful than the concentration of either metal [6]. Caeruloplasmin, an endogenous antioxidant and a major copper binder, is important in the interpretation of serum copper results [7]. Copper:caeruloplasmin ratio has recently been suggested as an alternative index of copper status $[8,9]$ that enables adjustment for relatively high caeruloplasmin levels without recourse to producing gender- and age-derived reference intervals [9].

Retinol and $\alpha$-tocopherol are essential micronutrients $[10,11] ; \alpha$-tocopherol is also a powerful antioxidant [11], but the benefits to humans of the potential antioxidant activity of retinol are not clear [12]. Serum $\alpha$-tocopherol:cholesterol ratio is considered a more reliable index of vitamin E nutrition than $\alpha$-tocopherol concentration alone [13].

This study aimed at establishing reference ranges for serum copper, zinc, retinol, $\alpha$-tocopherol levels, copper:caeruloplasmin and copper:zinc ratios in healthy Omani men and women, the effect of gender and age on them and to determine the prevalence of serum deficiency of these parameters.

\section{Materials and Methods}

The institutional Medical Research and Ethics Committees approved the study and informed consent was obtained from the participating subjects before the study. Exclusion criteria were pregnancy, females on oral contraceptives, subjects with clinical conditions such as malabsorption, hyperlipidaemia, hepatic disorders and persons on medication (cholestyramine, neomycin, mineral oil, antacid, phenobarbitone, cortisone). Two-fifty Omani indigenes comprising men $(n=130$, aged $18-62$ years, mean 30.3$)$ and women $(n=120$, aged $18-60$ years, mean 32.3$)$, who were apparently healthy, with no infection or chronic inflammatory disease, were enrolled. None of the subjects ingested micronutrient supplements. Menopausal women (aged $>40$ years) numbered 21 . Thirty-four men and 1 woman were smokers.

Fasting blood samples were drawn from each subject into plastic tubes (W. Sarstedt, Inc., Princeton, N.J., USA) to avoid contamination of copper and zinc. They were kept in the dark to clot
Table 1. Electrothermal furnace programme for copper analysis

\begin{tabular}{ccl}
\hline Temperature & Ramp, s & Hold, s \\
\hline $110^{\circ} \mathrm{C}$ & 3 & 30 (drying) \\
$130^{\circ} \mathrm{C}$ & 15 & 30 (drying) \\
$1,200^{\circ} \mathrm{C}$ & 10 & 20 (ashing) \\
$2,300^{\circ} \mathrm{C}$ & 0 & 5 (atomization) \\
$2,400^{\circ} \mathrm{C}$ & 1 & 3 (cleaning) \\
\hline
\end{tabular}

followed by centrifugation at 2,000 rpm for $10 \mathrm{~min}$. Using disposable plastic pipettes, haemolysis-free serum was separated from the cells into Beckman microfuge tubes (Beckman Instruments), wrapped in foil to prevent photodecomposition of retinol and $\alpha$ tocopherol and frozen at $-80^{\circ} \mathrm{C}$ pending analyses within a fortnight.

The electrothermal AAS copper method of Evenson and Warren [14] was modified for copper analysis on Model 600 atomic absorption spectrophotometer (PerkinElmer Corp., PTE Ltd., Singapore). Essentially, after calibration with copper working standards, the controls and samples were diluted 20 -fold with $0.1 \% \mathrm{HNO}_{3}$, followed by auto-injection of $20-\mu \mathrm{l}$ aliquot into the graphite cuvette for analysis. Analysis sequence and monitoring at $324.7 \mathrm{~nm}$ (copper emission line) using the furnace program are shown in table 1 .

Zinc measurement by flame AAS on a Shimadzu 6800 (Shimadzu, Kyoto, Japan) interfaced to a PC integrator and a printout system was based on a previously described method [15]. Trace Element Control Serum Levels I and II (Utak Laboratories, Inc., 25020 Avenue Tibbits, Valencia, Calif., USA) were used to monitor serum copper and zinc levels.

Analysis of serum concentrations of retinol and $\alpha$-tocopherol by reverse-phase HPLC followed a previous method [16], with modification. Essentially, the modification was the use of photodiode array that continuously monitored the column effluents over a selected wavelength range of $210-400 \mathrm{~nm}$ that covered the wavelength maxima of retinol (325 nm), $\alpha$-tocopherol $(292 \mathrm{~nm})$ and $\alpha$-tocopherol acetate as internal standard $(285 \mathrm{~nm})$. Quality control was monitored by using control levels I and II (Chromsystems Instruments and Chemicals $\mathrm{GmbH}$, München, Germany) (table 2).

IMMAGE Immunochemistry system was used to measure caeruloplasmin by rate immunonephelometry using Vigil Protein QC levels I, II and III as reference material (Beckman Coulter, USA). Albumin and cholesterol levels were measured by routine spectrophotometric methods on the Beckman Synchron CX7 clinical chemistry system with Multiqual levels I, II and III (Biorad Laboratories, Irvine, Calif., USA) as reference material.

Statistical analyses were performed using SPSS 11.0 for Windows software (SPSS, Chicago, Ill., USA). Because histogram plots to assess the relative frequency of concentrations showed normal curves for all the tests, reference ranges were established using parametric test. The reference range data were reported as mean \pm SD with $95 \%$ confidence interval (CI) in the result tables. Differences between two groups were evaluated by independent sample $t$ tests. Correlation analyses were performed. Probability $(\mathrm{p})$ values were two-tailed; $\mathrm{p}<0.05$ was considered significant. 
Table 2. Imprecision studies of internal quality control sera

\begin{tabular}{|c|c|c|c|c|c|c|c|}
\hline & \multirow[b]{2}{*}{ Analyte levels: } & \multicolumn{3}{|c|}{ Intra-batch CV, $\%(\mathrm{n}=11)$} & \multicolumn{3}{|c|}{ Inter-batch CV, \% } \\
\hline & & I & II & III & I & II & III \\
\hline Copper & & 2.6 & 2.7 & 2.4 & 4.3 & 4.7 & 4.8 \\
\hline Zinc & & 1.7 & 2.4 & 1.7 & 3.5 & 3.8 & 3.7 \\
\hline Caeruloplasmin & & 7.2 & 4.2 & 6.5 & 8.4 & 6.1 & 6.6 \\
\hline Albumin & & 0.9 & 1.3 & 1.2 & 2.0 & 2.8 & 2.3 \\
\hline Cholesterol & & 1.4 & 1.1 & 1.4 & 2.5 & 2.4 & 2.9 \\
\hline Retinol & & 3.3 & 3.1 & n.a. & 5.0 & 6.1 & n.a. \\
\hline$\alpha$-Tocopherol & & 4.8 & 4.5 & n.a. & 6.6 & 7.2 & n.a. \\
\hline
\end{tabular}

The mean \% recoveries for retinol and $\alpha$-tocopherol obtained by spiking sera with known concentrations $(\mu \mathrm{M})$ of 2.0 and 12.0 of the respective analytes were $98(\mathrm{n}=5)$ and $96(\mathrm{n}=5)$, respectively. Inter-batch CV values were obtained from analyses on 20 consequent days.

Table 3. Mean \pm SD and $95 \%$ CI of serum parameters in a representative sample of Omani men and women

\begin{tabular}{lcccc}
\hline Parameter & Total & Men & Women & p value $^{1}$ \\
\hline Copper, $\mu \mathrm{M}$ & $15.9 \pm 3.0$ & $14.2 \pm 2.7$ & $17.8 \pm 2.1$ & $<0.0001$ \\
$\quad$ 95\% CI & $10.2-21.3$ & $9.8-21.0$ & $13.5-22.3$ & \\
Zinc, $\mu \mathrm{M}$ & $14.2 \pm 2.0$ & $15.0 \pm 2.2$ & $13.4 \pm 1.5$ & $<0.0001$ \\
$\quad$ 95\% CI & $11.0-19.8$ & $10.5-20.6$ & $11.1-17.4$ & \\
Cu:Zn, $\mu \mathrm{M} / \mu \mathrm{M}$ & $1.15 \pm 0.30$ & $0.97 \pm 0.24$ & $1.34 \pm 0.24$ & $<0.0001$ \\
$\quad$ 95\% CI & $0.69-1.60$ & $0.59-1.40$ & $0.95-1.71$ & \\
Caeruloplasmin, g/l & $0.301 \pm 0.044$ & $0.291 \pm 0.053$ & $0.312 \pm 0.028$ & $<0.0001$ \\
$\quad$ 95\% CI & $0.215-0.427$ & $0.207-0.439$ & $0.257-0.354$ & \\
Cu:caeruloplasmin, $\mu \mathrm{mol} / \mathrm{g}$ & $6.99 \pm 0.84$ & $6.49 \pm 0.81$ & $7.53 \pm 0.45$ & $<0.0001$ \\
$\quad$ 95\% CI & $5.46-8.14$ & $5.03-7.70$ & $6.86-8.21$ & \\
Retinol, $\mu \mathrm{M}$ & $1.45 \pm 0.39$ & $1.69 \pm 0.39$ & $1.20 \pm 0.20$ & $<0.0001$ \\
$\quad$ 95\% CI & $0.62-1.65$ & $0.66-1.80$ & $0.55-1.15$ & \\
$\alpha$-Tocopherol, $\mu \mathrm{M}$ & $16.9 \pm 4.4$ & $18.1 \pm 5.8$ & $15.6 \pm 1.4$ & $<0.0001$ \\
$\quad$ 95\% CI & $10.3-30.3$ & $9.1-33.8$ & $13.1-20.0$ & \\
Cholesterol, mmol/l & $4.5 \pm 0.7$ & $4.7 \pm 0.9$ & $4.4 \pm 0.4$ & $<0.0001$ \\
$\quad$ 95\% CI & $3.3-6.5$ & $3.1-7.1$ & $3.7-5.3$ & \\
$\alpha$-Tocopherol:cholesterol, $\mu \mathrm{M} / \mathrm{mM}$ & $3.71 \pm 0.64$ & $3.81 \pm 0.85$ & $3.60 \pm 0.22$ & $<0.0001$ \\
$\quad$ 95\% CI & $2.19-5.27$ & $2.14-5.82$ & $3.0-4.2$ & \\
Albumin, g/l & $45.1 \pm 2.3$ & $45.3 \pm 2.4$ & $44.9 \pm 2.2$ & 0.166 \\
$\quad$ 95\% CI & $40.0-50.0$ & $40.3-50.0$ & $39.0-49.0$ & \\
\hline
\end{tabular}

Statistical significance was considered at $\mathrm{p}<0.05 .{ }^{1}$ Men versus women.

\section{Results}

The mean \pm SD and 95\% CI values for all the parameters of the study group are presented in table 3. The serum copper and caeruloplasmin levels were much higher $(\mathrm{p}<0.0001)$ in women compared to men. The same also applied to copper:zinc and copper:caeruloplasmin ratios.
Higher Zn, retinol, $\alpha$-tocopherol, cholesterol concentrations $(\mathrm{p}<0.0001)$ and $\alpha$-tocopherol:cholesterol ratio $(\mathrm{p}=$ 0.006 ) were observed in men. Incidences of deficiency of the micronutrients and their ratios, considered at below reference range values, were between 1 and $4 \%$.

Correlation analyses of the relationship between age and various biochemical parameters for men and women 
Table 4. Relationship between age and the parameters in Omani men and women

\begin{tabular}{|c|c|c|c|c|}
\hline \multirow[t]{2}{*}{ Parameter } & \multicolumn{2}{|c|}{ Men $(n=130)$} & \multicolumn{2}{|c|}{ Women $(\mathrm{n}=120)$} \\
\hline & $\mathrm{r}$ & $\mathrm{p}$ value & $\mathrm{r}$ & $\mathrm{p}$ value \\
\hline Copper & 0.249 & 0.004 & 0.439 & $<0.0001$ \\
\hline Zinc & -0.007 & 0.938 & 0.163 & 0.076 \\
\hline Copper:zinc & 0.191 & 0.029 & 0.158 & 0.085 \\
\hline Caeruloplasmin & 0.417 & $<0.0001$ & 0.302 & 0.001 \\
\hline Cu:caeruloplasmin & -0.234 & 0.007 & 0.386 & $<0.0001$ \\
\hline Retinol & 0.150 & 0.088 & 0.508 & $<0.0001$ \\
\hline$\alpha$-Tocopherol & 0.625 & $<0.0001$ & 0.113 & 0.221 \\
\hline Cholesterol & 0.562 & $<0.0001$ & 0.267 & 0.003 \\
\hline$\alpha$-Tocopherol: & & & & \\
\hline cholesterol & 0.368 & $<0.0001$ & -0.223 & 0.015 \\
\hline Albumin & -0.351 & $<0.0001$ & 0.011 & 0.905 \\
\hline
\end{tabular}

Table 5. Effect of cigarette smoking on plasma levels of some biochemical parameters in Omani men

\begin{tabular}{lccc}
\hline Parameter & $\begin{array}{l}\text { Smokers } \\
(\mathrm{n}=34)\end{array}$ & $\begin{array}{l}\text { Non-smokers } \\
(\mathrm{n}=96)\end{array}$ & $\begin{array}{l}\mathrm{p} \\
\text { value }\end{array}$ \\
\hline Copper, $\mu \mathrm{M}$ & $13.9 \pm 2.5$ & $14.3 \pm 2.8$ & 0.477 \\
Zinc, $\mu \mathrm{M}$ & $14.2 \pm 1.4$ & $15.1 \pm 2.4$ & 0.023 \\
Copper:zinc, $\mu \mathrm{M} / \mu \mathrm{M}$ & $0.99 \pm 0.24$ & $0.97 \pm 0.28$ & 0.727 \\
Caeruloplasmin, g/l & $0.306 \pm 0.054$ & $0.289 \pm 0.055$ & 0.112 \\
Cu:caeruloplasmin, $\mu \mathrm{mol} / \mathrm{g}$ & $6.06 \pm 0.81$ & $6.58 \pm 0.81$ & 0.002 \\
Retinol, $\mu \mathrm{M}$ & $1.14 \pm 0.23$ & $1.11 \pm 0.27$ & 0.576 \\
$\alpha$-Tocopherol, $\mu \mathrm{M}$ & $20.2 \pm 5.2$ & $17.6 \pm 5.9$ & 0.016 \\
Cholesterol, mM & $4.9 \pm 1.0$ & $4.6 \pm 0.9$ & 0.211 \\
$\alpha$-Tocopherol:cholesterol, & & & \\
$\quad \mu \mathrm{M} / \mathrm{mM}$ & $4.11 \pm 0.70$ & $3.76 \pm 0.89$ & 0.021 \\
Albumin, g/l & $44 \pm 1$ & $46 \pm 3$ & 0.002 \\
\hline
\end{tabular}

Statistical significance was considered at $\mathrm{p}<0.05$.

are shown in table 4 . There was a moderate association between copper and age in women $(r=0.439)$, but not in men. A similar effect of age was observed for caeruloplasmin, $\alpha$-tocopherol, cholesterol and $\alpha$-tocopherol:cholesterol ratio (with significant $r$ values being $0.417,0.625$, 0.562 , and 0.368 , respectively) in men, and for retinol in women $(r=0.508)$. A weak but negative relationship was seen between age and albumin $(r=-0.351)$ in men. The
Table 6. Mean plasma micronutrient concentrations and copper:caeruloplasmin ratios reported for various countries

\begin{tabular}{|c|c|c|c|c|c|c|}
\hline Country & $\mu \mathrm{M}$ & $\mu \mathrm{M}$ & $\mu \mathrm{M}$ & $\begin{array}{l}\alpha-\text { To- } \\
\text { coph- } \\
\text { erol } \\
\mu \mathrm{M}\end{array}$ & $\begin{array}{l}\text { Cu:caerulo- } \\
\text { plasmin } \\
\text { ratio } \\
\mu \mathrm{mol} / \mathrm{g}\end{array}$ & Ref. \\
\hline Oman & 15.9 & 14.2 & 1.45 & 16.9 & 6.99 & $\begin{array}{l}\text { this } \\
\text { study }\end{array}$ \\
\hline UK & & & & & 6.81 & 6 \\
\hline Kuwait & 23.2 & 16.1 & 1.76 & 20.0 & & 13,14 \\
\hline Japan & & & 2.60 & 24.4 & & 16 \\
\hline Italy & & & 2.09 & 26.2 & & 17 \\
\hline Spain & & & 1.70 & 28.2 & & 18 \\
\hline USA & & & 1.91 & 25.7 & & 19 \\
\hline Switzerland & & & 2.09 & 29.3 & & 20 \\
\hline Thailand & 18.0 & 12.7 & & & & 22 \\
\hline Norway & 17.5 & 15.5 & & & & 23 \\
\hline N. Ireland & 18.1 & 12.4 & & & & 24 \\
\hline Canary & 17.3 & 17.7 & & & & 25 \\
\hline
\end{tabular}

effect of smoking on the parameters in men is shown in table 5. Smokers had significantly lower zinc and albumin concentrations and copper:caeruloplasmin ratio than non-smokers. Higher $\alpha$-tocopherol concentration and $\alpha$-tocopherol:cholesterol ratio were observed in smokers compared to non-smokers.

The mean values for the micronutrients and copper:caeruloplasmin ratio published for different countries are presented in table 6. Omani mean values for retinol, $\alpha$-tocopherol, and copper were lower relative to reported mean values for Americans, Europeans, the Japanese, Kuwaitis and Thais. Their mean zinc value was lower than the values reported for the Norwegians and Canarians, but higher compared to the mean for Greeks, the Irish and Thais. The Omani mean for the copper:caeruloplasmin ratio was similar to the value reported for the UK population.

\section{Discussion}

The mean values of serum copper, zinc, retinol, $\alpha$-tocopherol, caeruloplasmin, albumin and cholesterol for Omanis were within the established reference ranges [2]. However, compared with other populations, like Kuwaiti, Japanese, Italian, Spanish, American and Swiss populations [16-20] (table 6), the mean values of retinol and $\alpha$ tocopherol obtained for Omanis were lower. Similarly, 
the Omani mean for copper was lower compared to those of Kuwaitis, Thais, Greeks, Norwegians, the Irish and Canarians [15, 21-25]. Omani mean for zinc levels varied and was higher than the values reported for Thais [21], Greeks [22] and Norwegians [23], but lower than those of the Irish and Canarians $[24,25]$. These findings may have two explanations. Firstly, the method specificity may be higher here than in earlier studies, which may be attributable to improvement of the relevant analytical techniques over the years. Secondly, for Omanis, the dietary habits reflecting their affluence and purchasing power may be different from those of Kuwaitis, the Japanese and Westerners. The Japanese and the Westerners would also be expected to be nutritionally more aware and are likely to ingest nutrient supplements.

Gender was an important determinant as serum copper values being higher in women than men (table 3 ) even though the exclusion criteria included pregnancy and intake of oral contraceptives. High serum copper values seen in Omani women corroborated reports for women of Kuwaiti, Thai, and Western populations. Gender influence was also noticeable for zinc and retinol levels, which were higher in men than in women (table 3); the high retinol levels contrasted with the report by Winklhofer-Roob et al. [20], but confirmed other studies [1619]. The finding here of lower $\alpha$-tocopherollevel in Omani women than men is at discord with the study by Ito et al. [17] on the Japanese.

The present study's copper:caeruloplasmin ratio (mean $\pm \mathrm{SD}, \mu \mathrm{mol} / \mathrm{g}$ ) of $6.99 \pm 0.84$ (table 3) is similar to $6.81 \pm 0.87$ reported by Twomey et al. [9]. Also, the Omani reference range of 5.46-8.14 $\mu \mathrm{mol} / \mathrm{g}$ for copper:caeruloplasmin ratio (table 3 ) is close to $5.2-7.3$ and $5.08-8.55 \mu \mathrm{mol} / \mathrm{g}$ Beetham [8] and Twomey et al. [9] reported, respectively. Furthermore, Omani reference ranges of $10.2-21.3 \mu \mathrm{M}$ (copper) and $0.215-0.427 \mathrm{~g} / \mathrm{l}$ (caeruloplasmin) are similar to the 10-25 $\mu \mathrm{M}$ (copper) and $0.200-0.500 \mathrm{~g} / \mathrm{l}$ (caeruloplasmin) reported by Twomey et al. [9]. However, the observation that the copper:caeruloplasmin ratio was markedly higher in women compared to men (table 3 ) contrasted with the previous reports $[8$, 9]. The persistent gender effect found here may be related to the types of subjects in the present study and that of Twomey et al. [9]. A sizeable number of patients in the study by Twomey et al. [9] had liver disorders that impinge on the capacity to synthesize caeruloplasmin compared to the hepatic synthetic capacity of healthy Omani women. Twomey et al. [9] did not indicate the ratio of women to men in their study.
Depressed copper and elevated zinc is a common trace-metal imbalance; copper and zinc compete for ligands and impair each other's function [2]. Absorbed dietary zinc acts directly with a nuclear metalloregulatory binding protein that controls the synthesis of metallothionein, an avid copper binder in the intestinal mucosal cells [2]. Thus, when mucosal cells are rich in metallothionein, little copper traverses the cells into the blood, because most of the copper is returned to the intestinal lumen when intestinal cells turn over [2]. The reference range for copper:zinc ratios of $0.69-1.60($ mean $=1.15)$ reported here is comparable to the stated optimum of $0.70-1.00$ [5]. A deficiency of $4 \%$ obtained for the Omanis may be insignificant.

The effect of age on the parameters varied and was dependent on gender (table 4). Copper concentration increased with age, and more so in women than in men contrasting with caeruloplasmin. The copper:caeruloplasmin ratio complemented copper in that it increased with age in women, but unlike copper it negatively correlated with age in men. There is no previous study to compare these findings with. The increased caeruloplasmin in the aging males may be an acute-phase response to rising inflammation consistent with ageing. Serum albumin levels correlate with nutritional parameters including anthropometric measurements [4]. Albumin measured in this study primarily as a marker of nutrition adequacy was negatively associated with age in men, which may portend diminishing hepatic synthesis in ageing men than women [26].

$\alpha$-Tocopherol concentrations are frequently adjusted for plasma cholesterol concentrations to avoid misclassification of vitamin E status [13]. A stronger association of $\alpha$-tocopherol:cholesterol ratio with age in men compared to women (table 4) suggests greater antioxidant protection for the former group against lipid peroxidation and atherosclerotic lesion [11]. The 1-3\% incidence of deficiency of $\alpha$-tocopherol and of $\alpha$-tocopherol:cholesterol ratio in Omani men and women is unlikely to be of any real significance. The relationship of serum cholesterol concentration with age was less striking in women than in men. That retinol level related with age in Omani women may mean improved aging-related immunity [10]. The benefits to humans of the potential antioxidant activity of retinol are not clear [12].

Cigarette smoke is implicated in free radical-related cytotoxicity [27]. Albumin, an antioxidant and a major zinc binder and transporter [2], complemented zinc in depletion in smokers relative to non-smokers (table 5), possibly implying a connection between cigarette smoke 
cytotoxicity and the hepatic synthesis of albumin. Conversely, increased $\alpha$-tocopherol level and $\alpha$-tocopherol:cholesterol ratio in smokers compared with nonsmokers may confer antioxidant protection against the deleterious effect of smoking [28]. Previous studies have also reported varied effects of smoking on biological antioxidant status $[28,29]$.

\section{Conclusion}

This study has shown that in the Omani population, the serum concentrations of copper, zinc, retinol, $\alpha$-tocopherol and copper:caeruloplasmin ratio are influenced by gender. The mean values of several micronutrients were lower than the corresponding values reported for other populations.

\section{References}

1 Status of Health Program, Annual Health Report, Ministry of Health, Sultanate of Oman, 2006, vol 8, tables 8.13-8.16.

2 Shenkin A, Baines M, Fell GS, Lyon TDG: Vitamins and trace elements; in Burtis CA, Ashwood ER, Bruns DE (eds): Tietz Textbook of Clinical Chemistry and Molecular Diagnostics, ed 4. St Louis, Elsevier Saunders, 2006, pp 1075-1164.

3 Kelleher SL, Lonnerdal B: Long-term marginal intakes of zinc and retinol affect retinol homeostasis without compromising circulating levels during lactation in rats. J Nutr 2001;131:3237-3242.

-4 Kuzuya M, Izawa S, Enoki H, Okada K, Iguchi A: Is serum albumin a good marker for malnutrition in the physically impaired elderly? Clin Nutr 2007;26:84-90.

5 Irving JA, Mattman A, Lockitch G, Farrell K, Wadsworth LD: A case of reversible cytopenias associated with excessive zinc supplementation. CMAJ 2003;169:129-131.

6 Rowin J, Lewis SL: Copper deficiency myeloneuropathy and pancytopenia secondary to overuse of zinc supplementation. J Neurol Neurosurg Psychiatry 2005;76:750-751.

7 Walshe JM: Wilson's disease: the importance of measuring serum caeruloplasmin nonimmunologically. Ann Clin Biochem 2003; 40:115-121.

8 Beetham R: Use of serum copper to caeruloplasmin ratio to highlight relative copper excess in Wilson' disease. Ann Clin Biochem 2006;43(suppl 1):53.

-9 Twomey PJ, Viljoen A, House IM, Reynolds TM, Wierzbicki AS: Copper:caeruloplasmin ratio. J Clin Pathol 2007;60:441-442.

10 Russell RM: The vitamin A spectrum: from deficiency to toxicity. Am J Clin Nutr 2000; 71:878-884.

11 Burton GW, Ingold KU: Vitamin E as an in vitro and in vivo antioxidant. Ann NY Acad Sci 1989;570:7-22.
12 Kris-Etherton PM, Lichtenstein AH, Howard BV, Steinberg D, Witztum JL: Antioxidant vitamin supplements and cardiovascular disease. Circulation 2004;110:637-641.

13 Thurnham DL, Davies JA, Crump BJ, Situnayake RD, Davies M: The use of different lipids to express serum tocopherol:lipid ratios for the measurement of vitamin E status. Ann Clin Biochem 1986;23:514-520.

14 Evenson MA, Warren BL: Determination of serum copper by atomic absorption with use of the graphite cuvette. Clin Chem 1975;21: 619-625.

15 Abiaka C, Olusi S, Al-Awadhi A: Reference ranges of copper and zinc and the prevalence of their deficiencies in an Arab population aged $15-80$ years. Biol Trace Elem Res 2003; 91:33-43.

16 Abiaka C, Olusi S, Simbeye A: Serum concentrations of micronutrient antioxidants in an adult Arab population. Asia Pac J Clin Nutr 2002;11:22-27.

17 Ito Y, Ochiai J, Sasaki R, Suzuli S, Kasuhara Y, Morimitsu Y, Otani M, Aoki K: Serum concentration of carotenoids, retinol, and $\alpha$ tocopherol in healthy persons determined by high performance liquid chromatography. Clin Chim Acta 1990;194:131-144.

18 Caperle M, Maiani G, Azzini E, Conti E, Raguzzini A, Ramazzotti V, Crespi M: Dietary profiles and antioxidants in a rural population of central Italy with a low frequency of cancer. Eur J Cancer Prev 1996;5:197-206.

19 Omedilla B, Granado F, Gil-Martinez E, Blanco I, Rojas Hidalgo E: Reference values for retinol, tocopherol, and main carotenoids in serum of control and insulin-dependent diabetic Spanish subjects. Clin Chem 1997; 43:1066-1071.

20 Winklhofer-Roob BM, van't Hof MA, Shmerling DH: Reference values for plasma concentrations of vitamins $\mathrm{E}, \mathrm{A}$ and carotenoids in a Swiss population from infancy to adulthood, adjusted for seasonal influences. Clin Chem 1997;43:146-153.
21 Songchitsomboon S, Komindr S: Serum copper and zinc in healthy adults living in Bangkok and surrounding districts. J Med Assoc Thai 1996;79:550-557.

22 Kouremenou-Dona E, Dona A, Papoutsis J, Spiliopoulou C: Copper and zinc concentrations in healthy Greek adults. Sci Total Environ 2006;359:76-81.

23 Helgeland K, Haider T, Jonsen J: Copper and zinc in human serum in Norway: relationship to geography, sex and age. Scand J Clin Lab Invest 1982;42:35-39.

- 24 McMaster D, McCrum E, Patterson CC, Kerr MM, O'Reilly D, Evans AE, Love AH: Serum copper and zinc in random sample of the population of Northern Ireland. Am J Clin Nutr 1992;56:440-446.

25 Diaz RC, Henriquez SP, Lopez BF, Rodriguez RE, Serra ML: Serum copper and zinc concentrations in a representative sample of the Canarian population. J Trace Elem Med Biol 2002;16:75-81.

26 Schalk BWM, Visser M, Deeg DJH, Bouter LM: Lower levels of serum albumin and total cholesterol and future decline in functional performance in older persons: the Longitudinal Aging Study Amsterdam. Age Ageing 2004;33:266-272.

27 Culcasi M, Muller A, Mercier A, Clement JL, Payet O, Rockenbauer A, Marchand V, Pietri $S$ : Early specific free radical-related cytotoxicity of gas phase cigarette smoke and its paradoxical temporary inhibition by tar: an electron paramagnetic resonance study with the spin trap DEPMPO. Chem Biol Interact 2006;164:215-231.

28 Chalmers P: Smoking and oxidative stress. Am J Clin Nutr 1999;69:572-575.

29 Zhou JF, Yan XF, Guo FZ, Sun NY, Qian ZJ, Ding DY: Effects of cigarette smoking and smoking cessation on plasma constituents and enzyme activities related to oxidative stress. Biomed Environ Sci 2000;13:44-55. 